4. Каменные угли Львовско-Волынского бассейна: кол. монографія / Вырвич Г.П., Гигашвили Э.П., Дубик З.Г. и др.; под общ. ред. В.З. Ершова. Львов: Выща шк. при Львов. ун-те. 1978. 175 с.

5. Львовско-Волынский каменноугольный бассейн: Геологопромышленный очерк: кол. монографія / М.И. Струев, В.И. Исаков, В.Б. Шпакова и др.; отв. ред. А.З. Широков. Киев: Наук. Думка. 1984. 272 c.

6. Porzycki J. Tektonika. Karbon Lubelskiego Zagltbia Weglowego. Prace Inst. Geol. 1988. T. 122. S. 9-18.

7. Porzycki J., Zdanowski A. Charakterystyka zlozowa i jakosc wegla. Karbon Lubelskiego Zagltbia Weglowego. Prace Inst. Geol. 1988. T. 122. S. 179-192.

DOI https://doi.org/10.30525/978-9934-26-111-4-43

\title{
PROCESSES AND FACTORS CONTROLLING THE GROUNDWATER CHEMISTRY OF THE PLEISTOCENE AQUIFER OF BLACK SEA ARTESIAN BASIN, SOUTH UKRAINE
}

\section{Melkonyan D. V.}

PhD (Physics and Mathematics), Associate Professor, Department of Engineering Geology and Hydrogeology

Odesa I. I. Mechnikov National University

\section{Cherkez E. A.}

Doctor of Sciences (Geology and Mineralogy), Professor, Department of Engineering Geology and Hydrogeology

Odesa I. I. Mechnikov National University

\section{Tyuremina V. H.}

PhD (Geology and Mineralogy), Chief geologist

LTD «Gidrogeoservice»

Odesa, Ukraine

Problem Statement and Purpose. In this paper the groundwater chemistry in a Pleistocene aquifer was analyzed to get insight into the factors affecting groundwater quality in a Southern Bug and Syniukha interfluve 
area. The study area is a typical agricultural and industrial area, located in the steppe zone of southern Ukraine and encompasses an area of $150 \mathrm{~km}^{2}$.

Groundwater is widely used by the local population in numerous boreholes for domestic and agricultural purposes. In the study area there are about 35 anthropogenic sources of groundwater pollution such as industrial and domestic landfills, pesticide and fertilizer storage, various livestock farm complexes, settling tanks, wastewater and solid waste discharges, etc. Groundwater table location close to the surface, its natural vulnerability to pollution, also its location in the lowest parts of the terrain leads to intensive pollution of groundwater. Besides, shallow groundwater in relation to the fractured water in Precambrian crystalline aquifer, that lies below and contains groundwater in sufficient quantities to be used for drinking water supply, serves as a protective screen and a source of pollution. The hydraulic connection exists between these aquifers, mainly in gullies or river valleys.

This implies that any environmental problems have emerged caused by contamination of drinking groundwater, for which the shallow groundwater might serve as an environmental indicator and play an important protective role. Thus, the identification of key factors (natural and anthropogenic) governing chemistry in groundwater may help to solve environmental problems in the study area and prevent hydrogeological hazards.

The purpose of this paper is to study the chemistry and indentify the processes and factors controlling the shallow groundwater chemistry in the Pleistocene sediments of the Southern Bug and Syniukha interfluve.

The available geochemical research of groundwater in the Pleistocene aquifer have been carried out for major ions chemistry [1;2]. But, till date, a comprehensive study, particularly on the geochemical nature of this aquifer groundwater is lacking. This study will therefore contribute towards the geochemical knowledge of the Pleistocene aquifer groundwater in the Boleslavchik village area (Southern Bug and Syniukha interfluve). In addition, the Boleslavchik village is chosen as the key study area because in this area groundwater showed the highest pollution.

Data and Methods. A total of 102 water samples were collected from groundwater wells and boreholes during the dry season (in the second half of June and until the first half of November) and were hydrochemically analyzed for their macrocomponent composition. Wells are located in the central part of the Boleslavchik village along the north-south and east-west profiles. Groundwater samples showed great variation of chemistry in the study area. Groundwater geochemical assessment was carried out using statistical methods in combination with conventional graphical methods. 
Results. Pleistocene aquifer sediments are composed mainly of sands, sandy loam, loam sometimes with carbonate, clay with gypsum crystals and silt sometimes with crystalline rocks. These sediments mainly consist of quartz, calcite, dolomite, gypsum and feldspar. Weathering and dissolution of these minerals can be a possible source of groundwater enrichment by different ions.

The dominant hydrochemical types of shallow groundwater identified from piper plots (Fig. 1) are $\mathrm{SO}_{4}-\mathrm{Na}, \mathrm{HCO}_{3}-\mathrm{Na}$ and mixed $\mathrm{SO}_{4}-\mathrm{Mg}-\mathrm{Na}$, $\mathrm{SO}_{4}-\mathrm{Ca}-\mathrm{Na}$ types, sometimes $\mathrm{NO}_{3}-\mathrm{HCO}_{3}$ and $\mathrm{NO}_{3}-\mathrm{Cl}-\mathrm{Na}$ types. The dominance of ions is in the order of $\mathrm{Na}^{+}+\mathrm{K}^{+}>\mathrm{Ca}^{2+}>\mathrm{Mg}^{2+}$ and $\mathrm{SO}_{4}{ }^{2-}>\mathrm{HCO}_{3}^{-}>\mathrm{Cl}^{-}>\mathrm{NO}_{3}{ }^{-}$. Gibbs diagram (Fig. 2) specifies that these groundwater types are formed under the influence of natural and anthropogenic factors, such as water-rock interaction, evaporationcrystallization, precipitation and anthropogenic impact. In this case, evaporation-crystallization, anthropogenic impact and water-rock interaction processes, such as silicate weathering which is supported by high $\mathrm{Na}^{+} / \mathrm{Cl}^{-}$ ratio [7] and Gibbs diagrams [6], carbonate minerals dissolution (supported by high $\left.\mathrm{HCO}_{3}{ }^{-}+\mathrm{SO}_{4}{ }^{2-} / \mathrm{Ca}^{2+}+\mathrm{Mg}^{2+}[3 ; 4 ; 10]\right)$, sulphate minerals dissolution (supported by $\mathrm{SO}_{4}{ }^{2-} / \mathrm{Ca}^{2+}$ [8]) and ion exchange (supported by ratio $\left.\left(\mathrm{Ca}^{2+}+\mathrm{Mg}^{2+}\right)-\left(\mathrm{SO}_{4}{ }^{2-}+\mathrm{HCO}_{3}{ }^{-}\right) /\left(\left(\mathrm{Na}^{+}+\mathrm{K}^{+}\right)-\mathrm{Cl}^{-}\right)=-1\right)$ [5]) play major roles. The Schoeller index values [9] are negative in about $98 \%$ of samples and also show cation-ion exchange.

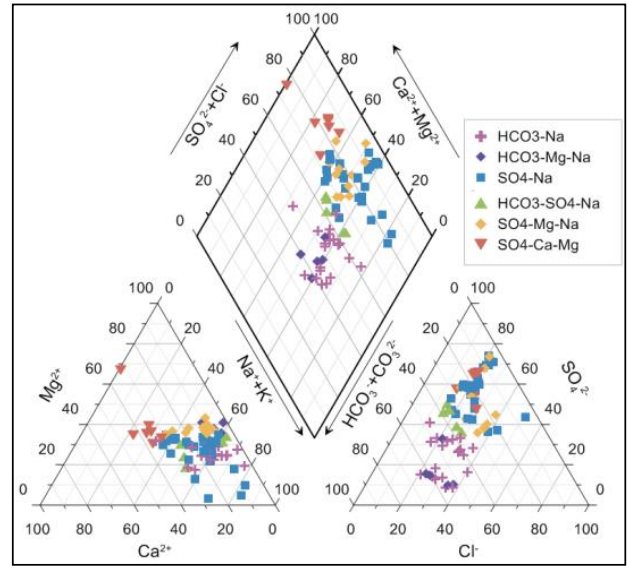

Fig. 1. Piper diagram showing the dominant groundwater types in the study area 

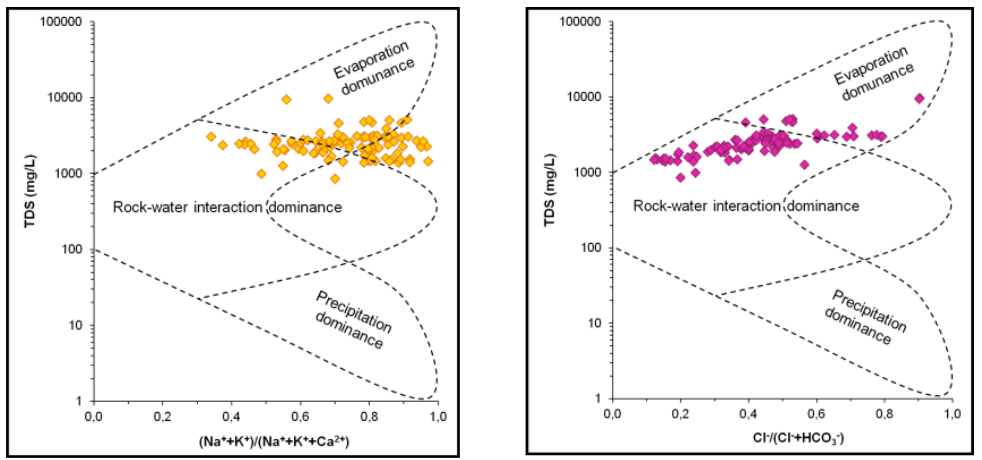

\section{Fig. 2. Gibbs plot highlighting the geochemical processes in the groundwater}

The high $\mathrm{Na}^{+}+\mathrm{K}^{+}$values of some water samples also indicate the presence of ion exchange processes. Within aquifers, $\mathrm{Ca}^{2+}$ and $\mathrm{Mg}^{2+}$ take the place of adsorbed $\mathrm{Na}^{+}$on aquifer solids through cation exchange processes. This leads to an increase in dissolved $\mathrm{Na}^{+}$concentrations and a decrease in dissolved $\mathrm{Ca}^{2+}$ and $\mathrm{Mg}^{2+}$ concentrations.

The ratio $\mathrm{Ca}^{2+} / \mathrm{Mg}^{2+}<1$ in about $80 \%$ of samples indicating the dissolution of dolomite; in about $17 \%$ of samples has a value between 1 and 2 indicating the dissolution of calcite. Just $3 \%$ of the samples have a value more than 2, which indicates the effect of silicate minerals on the groundwater chemistry. In addition, the $\left(\mathrm{Na}^{+}+\mathrm{K}^{+}\right) /($Total cations $)$ratios range from 0,01 to 0,82 , with $50 \%$ of the values less than 0,5 suggests that these cations in the groundwater might have been derived from silicate weathering.

Thus, the weathering of feldspars, chlorites and dissolution of calcites, dolomites are the primary sources for $\mathrm{Na}^{+}, \mathrm{K}^{+}, \mathrm{Mg}^{2+}, \mathrm{Ca}^{2+}$ ions, and dissolution of gypsum, sulphide mineralization for $\mathrm{SO}_{4}{ }^{2-}$ ions in groundwater in the study area.

The anthropogenic pollution may have a strong influence on the nitrate ions occurrence in the shallow groundwater. The revealed positive correlation between total dissolved solids (TDS) and $\left(\mathrm{NO}_{3}{ }^{-}+\mathrm{Cl}^{-}\right) / \mathrm{HCO}_{3}{ }^{-}$ confirms that water chemistry is influenced by anthropogenic activities. High concentrations of $\mathrm{Na}^{+}, \mathrm{Cl}^{-}, \mathrm{SO}_{4}{ }^{2-}, \mathrm{NO}_{3}{ }^{-}$in studied shallow groundwater reflect agricultural activity as the main source of these ions. This is mainly intensive use of fertilizers in agriculture, the release of untreated wastewater, etc. 


\section{References:}

1. Державна геологічна карта України, масштаб 1:200000. Серія Центральноукраїнська. Аркуш M-36-XXXI (Первомайськ). Пояснювальна записка. Київ: Державний комітет природних ресурсів України, Український державний геологорозвідувальний інститут, 2004. 175 с.

2. Звіт з проведення еколого-гідрогеологічного обстеження в зоні надзвичайної екологічної ситуації в Первомайському районі Миколаївської області (межиріччя П. Буг-Синюха) / «Причорномор ДРГП»; кер. теми В. Г. Тюремина; вик. А.В. Бруяко. Одеса, 2000. 132 с.

3. Datta P., Tyagi S. Major ion chemistry of groundwater in Delhi area: chemical weathering processes and groundwater flow regime. Journal of the Geological Society of India. 1996. Vol. 47(2). P. 179-188.

4. Elango L., Kannan R. Rock-water interaction and its control on chemical composition of groundwater. Developments in environmental science / D. Sarkar, R. Datta, R. Hannigan (eds.). 2007. Vol. 5. P. 229-243. https://doi:10.1016/S1474-8177(07)05011-5.

5. Garcia M. G., Hidalgo M. del V., Blessa M. A. Geochemistry of groundwater in the alluvial plain of Tucuman province. Argentina. Hydrogeology Journal. 2001. Vol. 9. P. 597-610.

6. Gibbs R. J. Mechanisms controlling world water chemistry. Science. 1970. Vol. 170. P. 1088-1090. DOI:10.1126/science. 170.3962.1088.

7. Mayback M. Global chemical weathering of surficial rocks estimated from river dissolved loads. American Journal of Science. 1987. Vol. 287. P. 401-428.

8. Purushothaman P., Someshwar Rao M., Rawat Y. S., Kumar C. P., Krishan G., Parveen T. Evaluation of hydrogeochemistry and water quality in Bist-Doab region, Punjab, India. Environmental Earth Sciences. 2013. Vol. 72. P. 693-706.

9. Schoeller H. Qualitative evaluation of groundwater resources. Methods and Techniques of Groundwater Investigations and Development. UNESCO. Paris, 1965. P. 54-83.

10. Tay C. K., Kortatsi B. K., Hayford E., Hodgson I. O. Origin of Major Dissolved Ions in Groundwater within the Lower Pra Basin using groundwater geochemistry, source-rock deduction and stable isotopes of ${ }^{2} \mathrm{H}$ and ${ }^{18} \mathrm{O}$. Environmental Earth Sciences. 2014. Vol. 71. P. 5079-5097. https://doi.org/10.1007/s12665-013-2912-z. 